\title{
KAJIAN SOSIO DEMOGRAFI DAN MANAJEMEN SUMBERDAYA TERHADAP KESEJAHTERAAN EKONOMI KELUARGA DI KABUPATEN KERINCI PROVINSI JAMBI
}

(Study of Resource Management and Socio Demographics on Economic Family Well-Being in Kerinci Regency of Jambi Province)

\author{
Suandi \\ Dosen Tetap pada Jurusan Sosial Ekonomi Pertanian \\ Fakultas Pertanian Universitas Jambi
}

\begin{abstract}
The objectives of this study are to identify and describe the level of family economic wellbeing as well as the socio-demographic and family resource management, and to analyze the influence of socio-demographic and management of resources factors on the economic well-being of family. The study design was cross sectional. The study was conducted in the Kerinci regency of Jambi Province. Research time for eigth months. Research variables: (1) the family's economic well-being (objective and subjective), (2) sociodemographic (education level, skills of heads of families, and the level of dependency ratio), and (3) management of family resources (management of time, number of family members, and financial management). The research sample were 174 households or ten percent of the population (1743 households) are chosen using cluster, purposive and random sampling methods. Data were collected using survay, indepth interview, and Focus Group Discussion (FGD). Data analysis using Structural Equation Modelling (SEM) with LISREL program (version 8.7).The results showed that the level of wellbeing families in the study area were relatively wealthy. Objective economic well-being of expenditure proxy for Rp.10.541.000 per year. The level of satisfaction or subjective economic well-being was highly (68.4\%) for daily needs. Through the SEM model testing showed that socio-demographic and family resource management variables, both directly and indirectly positive effect and significant on the level of economic well-being (objective and subjective) of the family with a value betha ( $\beta$ ) respectively, are 6.2 and 3.1.
\end{abstract}

Key words: socio-demographics, family resource management, and economic well-being of the family.

\section{PENDAHULUAN}

Apabila merujuk pada pola pembangunan Indonesia dalam Pasal 33 UUD 1945 yang memberi arah pembangunan ekonomi untuk menuju kesejahteraan sosial. Kata kunci pembangunan di Indonesia adalah kualitas SDM. Kemudian, UU RI No 25 tahun 2000 tentang Program Pembangunan 
Nasional (Propenas) tahun 2000-2004, pembangunan pangan dan gizi tercantum dalam bidang ekonomi serta sosial budaya. Hal ini jelas menunjukkan bahwa pembangunan ekonomi yang dikembangkan selama ini tidak berdampak positif terhadap kualitas SDM. Artinya adalah, setiap peningkatan pertumbuhan ekonomi, GDP dan pendapatan perkapita ternyata tidak berpengaruh positif terhadap peningkatan kualitas Sumber Daya Manusia. Kenyataan ini menunjukkan bahwa tujuan pembangunan untuk mewujudkan pembangunan Indonesia seutuhnya belum tercapai. Berkenaan dengan itu, arah pembangunan masa akan datang harus dilaksanakan secara holistik dan komprehensif dengan melibatkan keluarga sebagai subjek bukan sebagai objek pembangunan. Artinya, keluarga atau masyarakat harus diberdayakan sesuai dengan potensi dan kesempatan yang dimilikinya.

Hal ini sejalan dengan visi dan misi program Millenium Development Goals (MDGs) bahwa pemberantasan kemiskinan dan kelaparan berbasis pada masyarakat atau penduduk sehingga penduduk dunia pada tahun 2015, minimal separo dari target pembangunan bebas dari kemiskinan, kemelaratan dan sejenisnya (Anonim, 2003).

Penduduk Provinsi Jambi khususnya masyarakat yang berdomisili di Kabupaten Kerinci memiliki potensi sumberdaya manusia yang handal dan belum termanfaatkan dalam mendukung program pembangunan padahal mereka memiliki tingkat keterampilan yang tinggi khususnya kearifan local untuk memajukan pembangunan daerah umunya dan pembangunan masyarakat khususnya terutama masalah kesejahteraan penduduk. Mengingat sumberdaya penduduk atau keluarga yang berkembang di Kabupaten Kerinci memiliki kunikan dan kekhususan tersendiri karena berasal dari latar belakang budaya yang sama. Hal ini sejalan dengan pernyataan Deacon dan Firebough (Guhardja S et al., 2002), bahwa keluarga adalah unik karena setiap keluarga memiliki ciri yang berbeda satu dengan lainnya. Sebagai contoh, ada keluarga yang memiliki kekayaan sumberdaya yang berlebihan tetapi tingkat kesejahteran mereka relatif sama bahkan kadang-kadang lebih rendah dengan keluarga sumberdaya terbatas, dan sebaliknya keluarga yang memiliki kekayaan sumberdaya terbatas tetapi tingkat kesejahteraan mereka berkecukupan. Dengan adanya keunikan keluarga ini, sangat menarik untuk diteliti terutama keterkaitan keluarga dalam hal ini kesejahteraan ekonomi keluarga dengan faktor sumberdaya keluarga dan kondisi sosio-demografi? 


\section{TUJUAN PENELITIAN}

Tujuan umum penelitian adalah mengidentifikasi dan menganalisis tingkat kesejahteraan ekonomi keluarga dan kondisi sosio-demografi serta manajemen sumberdaya keluarga yang ada di daerah perdesaan Secara spesifik tujuan ini adalah:

1. Mengidentifikasi dan mengkaji tingkat kesejahteraan ekonomi keluarga,

2. Mengidentifikasi dan mengkaji kondisi sosio-demografi dan manajemen sumberdaya keluarga, dan

3. Menganalisis pengaruh faktor sosio-demografi dan manajemen sumberdaya keluarga terhadap kesejahteraan ekonomi keluarga.

\section{METODE PENELITIAN}

Desain penelitian adalah cross sectional. Penelitian dilakukan di Kabupaten Kerinci Provinsi Jambi dengan dua kecamatan terpilih, yaitu: Kecamatan Keliling Danau dan Kecamatan Batang Merangin. Terpilihnya kedua kecamatan tersebut sebagai wilayah penelitian dengan pertimbangan diharapkan dapat mewakili karakteristik kecamatan yang ada di Kabupaten Kerinci Provinsi Jambi baik dilihat dari aspek ekologi, ekonomi maupun sosial budaya.

Jenis atau variabel penelitian dibagi ke dalam ktiga kelompok, yaitu: sosio-demografi, manajemen sumberdaya keluarga, dan variabel kesejahteraan (objektif dan subjektif). Pertama, sosio-demografi (tingkat pendidikan, keterampilan kepala keluarga, dan tingkat beban ketergantungan), manajemen sumberdaya keluarga (manajemen waktu, jumlah anggota keluarga, dan manajemen keuangan). Ketiga, variabel kesejahteraan ekonomi keluarga (kesejahteraan ekonomi objektif dan kesejahteraan ekonomi subjektif).

Metode pengumpulan data dilakukan melalui wawancara dan observasi. Data penelitian ini bersumber dari data primer dan sekunder.Untuk mendapatkan data lebih mendalam, pengumpulan data dilanjutkan dengan metode wawancara mendalam (Indepth Interview) terhadap beberapa responden terpilih dan Focus Group Discussion (FGD). Perlu juga diketahui, pengumpulan data melalui wawancara mendalam dan FGD digunakan sebagai validasi data empiris yang diuji melalui model SEM. Artinya, hasil pembuktian data secara kuantitatif (analisis model SEM) didukung oleh analisis kualitatif yaitu data yang diperoleh dari hasil wawancara mendalam dan FGD. Responden (rumahtangga) diambil secara acak sederhana (simple random sampling) sebesar 174 orang atau 10 persen dari jumlah rumahtangga yang ada pada seluruh desa 
ISSN: 1412-8837

penelitian (1.743 rumahtangga).Analisis data menggunakan model Structural Equation Model (SEM)(Bollen, 1989) dengan program Linear Structural Releationship (LISREL) versi 8.7.

Tingkat validitas penelitian salah satunya ditentukan oleh reliabilitas instrumen atau tingkat konsistensi antar konstruk variabel penelitian. Untuk menguji besar kecilnya nilai reliabilitas instrument penelitian menggunakan tolok ukur nilai a-cronbach. Berdasarkan hasil pengujian diperoleh nilai acronbach penelitian berkisar antara 0,670 - 0,844. Dengan demikian, tingkat reliabilitas antar konstrak variabel penelitian atau informasi yang terjaring cukup dapat dihandalkan karena berdasarkan standar nilai paling rendah yaitu sebesar 0,60 (Myers, RH: Suandi, 2009).

\section{HASIL DAN PEMBAHASAN}

\section{Sosio Demografi Keluarga}

\section{Pendidikan Suami}

Persentase terbesar $(44,8 \%)$ kepala keluarga (suami) memiliki pendidikan Sekolah Dasar (SD) ke bawah. Artinya, mayoritas responden belum mencapai tingkat pendidikan dasar yang digariskan oleh pemerintah yaitu pendidikan 9 tahun. Padahal tingkat pendidikan cukup berperan dalam kelancaran penerimaan dan menjalankan teknologi baru termasuk teknologi pertanian.Hal ini dikhawatirkan dalam pengembangan sumberdaya manusia dan pembangunan daerah kedepan karena tingkat pendidikan yang rendah ini menjadi beban pemerintah kalau tidak diantisipasi dan melakukan berbagai terebosan pembangunan demi kamajuan masyarakat dan daerah. Dengan kondisi demikian, tingkat pengetahuan dan pemahaman masyarakat secara formal tergolong rendah termasuk kedalam tata cara pengelolaan rumahtangga. Padahal menurut Mubyarto (1992), bahwa tingkat pendidikan masyarakat perdesaan akan mempengaruhi cara berpikir dalam pengelolaan usahataninya terutama kemampuan manajemen, penerimaan inovasi baru dan pengambilan keputusan dalam memperhitungkan produktifitas usahatani mereka.

\section{Pendidikan Non Formal}

Tingkat pendidikan non formal suami (responden) atau kepala keluarga diambil dari banyak dan lamanya menekuni pendidikan non formal baik pada bidang keahlian maupun mendapat pendidikan atau pelatihan pada bidang lain sehingga dalam pengkategorian ada yang disebut dengan mereka yang sangat sering mengikuti pendidikan, sering mengikuti pendidikan, kurang mengikuti 
pendidikan, dan tidak pernah mengikuti pendidikan non formal. Berdasarkan hasil pengumpulan data melalui wawancara dan pengamatan lapangan diperoleh informasi bahwa rata-rata suami atau kepala keluarga keterlibatan mengikuti pendidikan non formal tergolong relatif rendah.Hal ini dapat dibuktikan melalui distribusi data responden yang berdasarkan jumlah pendidikan non formal yang diikuti, hampir separo responden tergolong pada kelompok yang terbatas mengikuti pendidikan non formal.Dengan arti kata, responden di daerah penelitian mayoritas tidak/belum pernah menerima pendidikan ataupun pelatihan dari istansi pemerintah/swasta baik pada bidang yang ditekuni maupun profesi lainnya.Rendahnya tingkat keterampilan suami di daerah penelitian akan berdampak kepada kesejahteraan ekonomi keluarga dan pembangunan daerah apalagi diperparah dengan rendahnya tingkat pendidikan formal yang dimiliki. Menurut hemat peneliti, perlu ada tindakan nyata "action" oleh pemerintah setempat kepada masyarakat secara umum dan responden khususnya dalam berbagai pemberdayaan baik secara kelompok maupun massal. Dengan harapan, semakin tinggi tingkat keterampilan masyarakat maka akan berpengaruh pada produktivitas kerja sehingga pada gilirannya akan berdampak pada naiknya pendapatan.

Khusus bagi responden yang memiliki keterampilan, tampaknya sebagian besar mengikuti pendidikan atau pelatihan di bidang pertanian yang dimotori oleh Dinas Pertanian Kabupaten dan Dinas Pertanian Provinsi, sedangkan keterampilan lain yang dimiliki responden yaitu mengikuti pelatihan di bidang teknik "las karbit" yang dilaksanakan oleh Departemen Tenaga Kerja dan Transmigrasi Kabupaten Kerinci.

\section{Tingkat Beban Ketergantungan Keluarga}

Komposisi penduduk responden di daerah penelitian menurut struktur umur penduduk masih tergolong muda namun hampir menuju pada struktur penduduk tua. Hal ini ditandai dengan persentase penduduk usia di bawah 15 tahun masih diatas angka 30 persen $(33,7 \%)$ dengan jumlah penduduk yang berumur di atas 65 tahun atau umur tidak produktif sebesar 1,8 persen. Dari data komposisi penduduk berdasarkan persentase penduduk muda dan tua akan dapat menentukan nilai dari beban ketergantungan suatu kelompok penduduk tersebut. Kalau kelompok umur 0-14 tahun dianggap sebagai kelompok penduduk yang belum produktif secara ekonomis, kelompok penduduk 15-64 tahun sebagai kelompok penduduk produktif, dan kelompok penduduk umur 65 tahun ke atas sebagai kelompok penduduk yang tidak 
produktif maka beban ketergantungan (dependency ratio) penduduk produktif di daerah penelitian sebesar 55. Artinya, dalam 100 orang usia produktif dari keluarga-keluarga contoh di daerah penelitian menanggung beban 55 orang yang berusia belum dan tidak produktif untuk kecukupan konsumtif. Hal ini mengindikasikan bahwa beban tanggungan bagi anggota keluarga usia produktif di daerah penelitian masih tergolong besar walaupun nilai beban ketergantungan ini lebih kecil dibandingkan dengan nilai rasio ketergantungan Propinsi Jambi tahun 2003 (56), dan bahkan nasional (Suandi, dan Bambang, 2003: 17). Angka beban ketergantungan tenaga kerja belum dan atau tidak produktif terhadap tenaga kerja produktif di daerah penelitian jauh lebih kecil bila dibandingkan dengan batas angka beban ketergantungan di Negara-negara berkembang (60) (Shryrock dan Siegel (1976:202). Relatif rendahnya tingkat ketergantungan penduduk belum dan tidak produktif terhadap penduduk produktif dapat mendorong terhadap kemajuan pembangunan selanjutnya. Mengingat angka rasio beban tanggungan sebagai faktor penentu pembangunan ekonomi karena sebagian dari pendapatan yang diperolah dari golongan yang produktif menentukan kebutuhan mereka yang belum produktif untuk kecukupan akan pangan, fasilitas pendidikan dan fasilitas lainnya (Mantra, 2000:92).

\section{Manajemen Sumberdaya Keluarga}

Seperti pada umumnya suatu sistem, sistem keluarga dalam memenuhi fungsinya menerima masukan (input) yang berupa: materi, energi, dan informasi yang memasuki sistem keluarga dan diklasifikasikan sebagai sumberdaya dan kebutuhan. Dalam keluarga, sumberdaya ini digunakan dalam rangka memenuhi kebutuhan keluarga. Sumberdaya yang telah digunakan ini akan keluar dari sistem keluarga sebagai output dan masuk sebagai input ke dalam sistem lingkungan. Kebutuhan merupakan "input" yang nenumbuhkan rangsangan, motivasi, dan arti pada kegiatan yang berlangsung di dalam sistem. Proses perubahan "input" dari materi, energi dan informasi menjadi "outpout" disebut througput atau transformasi.

Untuk mendapat variabel sumberdaya keluarga dalam satu kesatuan yang utuh maka perlu penggunaan sumberdaya keluarga dalam usaha atau proses mencapai sesuatu yang dianggap penting oleh keluarga. Hasil dari penggunaan sumberdaya diharapkan lebih baik dari pengorbanan (Guhardja S et al.,2002). Secara implisit dapat dijelaskan bahwa manajemen sumberdaya keluarga dapat dilihat dari dua pendekatan, pertama: manajemen sumberdaya 
keluarga terfokus pada pengalokasian tenaga dan waktu sesuai dengan peran anggota keluarga, dan pendekatan kedua bahwa manajemen sumberdaya keluarga dilihat dari proses dan manfaat dari sumberdaya itu sendiri. Sehubungan dengan itu, sesuai dengan tujuan penelitian maka penelitian ini menggunakan pendekatan kedua, yaitu melihat manajemen sumberdaya berdasarkan proses dan manfaat sumberdaya itu sendiri. Adapun sumberdaya yang di pakai sebagai variabel penelitian atau loading variabel dari manajemen adalah (1) manajemen sumberdaya waktu, (2) manajemen anggota keluarga, dan (3) manajemen keuangan keluarga.

\section{Manajemen Waktu}

Persentase manajemen waktu keluarga di daerah penelitian tergolong relatif baik.Terdapat hampir 65 persen keluarga responden di daerah penelitian menyatakan bahwa mereka merasa cukup baik dalam memanfaat waktu. Manajemen waktu dalam penelitian ini dilihat dari tiga aspek, yakni: aspek target jangka pendek, pemanfaatan waktu yang dimiliki, dan wujud kerja yang diharapkan. Dalam hal aspek target jangka pendek, rata-rata keluarga contoh di daerah penelitian yang bisa mencapai target yaitu mencapai 55 persen, dan sebaliknya terdapat sebanyak 45 persen keluarga contoh yang belum mencapai target yang ditentukan sebelumnya. Hasil yang diperoleh keluarga contoh di daerah penelitian ini sudah tergolong pada kelompok berhasil karena sudah dapat membuat perencanaan pemanfaatan waktu yang dimiliki. Pemanfaatan waktu jangka pendek keluarga contoh terutama dilihat pada kegiatan mencari nafkah (kebutuhan konsumsi pangan keluarga). Dimensi lain yaitu pemanfaatan waktu yang dimiliki anggota keluarga, hasil penelitian menunjukkan bahwa rata-rata pemanfaatan waktu juga menunjukkan hasil yang relatif baik dan melebihi persentase manajemen waktu dalam target jangka pendek $(65 \%)$. Kemudian, manajemen waktu dari aspek harapan yang diwujudkan oleh anggota keluarga contoh juga cukup tinggi yaitu mencapai 64 persen. Hal ini mengindikasikan bahwa keluarga contoh di daerah penelitian cukup baik dalam merencanakan sesuatu untuk kebutuhan keluarga dan dapat memanfaatkan sumberdaya dengan sebaik-baiknya sebagai keperluan keluarga.

\section{Manajemen Anggota Keluarga}

Rata-rata manajemen sumberdaya anggota keluarga di daerah penelitian sedikit lebih baik dibandingkan dengan manajemen sumberdaya waktu (71 persen). Manajemen sumberdaya anggota keluarga, seperti halnya dengan 
manajemen waktu yaitu mengandung beberapa aspek, yakni: dukungan psikologis terhadap kemajuan anak, manajemen anggota keluarga usia produktif, dan manajemen anggota keluarga lainnya. Berdasarkan hasil penelitian, ternyata ketiga aspek tersebut rata-rata tingkat manajemen atau pengelolaan sumberdaya tersebut tergolong tinggi yaitu berkisar antara 65,173,4 persen. Dari ketiga aspek tersebut, manajemen yang paling tinggi persentasenya terdapat dalam pengelolaan sumberdaya tenaga kerja produktif yaitu mencapai 73,4 persen, sedangkan persentase terendah yaitu manajemen terhadap dukungan psikologis kemajuan anak $(65,1 \%)$.

Relatif rendahnya dukungan psikologis keluarga contoh (orang tua) terhadap kemajuan anak terutama pendidikan disebabkan oleh tingkat pengetahuan orang tua yang rendah disamping waktu yang terbatas. Artinya, keluarga contoh (orang tua) di daerah penelitian mayoritas waktu diperuntukkan untuk bekerja.Lain halnya dengan manajemen anggota keluarga produktif. Hasil pengamatan lapangan menunjukkan bahwa rata-rata anggota keluarga produktif ( $\geq 15$ tahun atau tidak sedang dalam bangku sekolah) di daerah penelitian selalu membantu pekerjaan orang tua (kepala keluarga dan atau ibu) baik pekerjaan domestik maupun pekerjaan publik.

\section{Manajemen Keuangan Keluarga}

Manajemen keuangan keluarga sangat penting dalam memajukan kesejahteraan ekonomi keluarga baik dalam pengalokasian untuk kebutuhan konsumsi maupun keperluan investasi atau pengembangan usaha.Rata-rata manajemen atau pengelolaan keuangan keluarga di daerah penelitian yang termasuk pada kelompok baik dan sangat baik yaitu mencapai 60 persen.Hal ini mengindikasikan bahwa manajemen keluarga di daerah penelitian tergolong baik dan dapat dikategorikan sebagai petani maju.Padahal menurut hasil penelitian sebelumnya bahwa rata-rata petani di daerah perdesaan tingkat manajemennya sangat terbatas (Suandi, 1998 dan Suandi, 2000). Seperti halnya dengan manajemen lainnya, manajemen keuangan mengandung lima aspek, yakni: strategi mendapatkan penghasilan, alokasi belanja keperluan konsumsi, alokasi belanja keperluan produktif, manajemen biaya pendidikan anak (pendidikan formal dan non formal), dan manajemen pengembangan usaha. Berdasarkan hasil perhitungan diperloleh gambaran bahwa manajemen yang baik paling tinggi terdapat pada manajemen belanja untuk keperluan produktif yaitu mencapai 65 persen, sedangkan terendah terdapat pada manajemen pengembangan usaha hanya 54 persen. Angka ini sudah cukup representatif 
dari manajemen yang tergolong baik dan sangat baik. Khusus yang berkaitan dengan manajemen pengembangan usaha, hasil temuan di lapangan menyimpulkan bahwa terbatasnya kemampuan cara petani atau responden dalam mengelola atau merencanakan berbagai usaha kedepan untuk kemajuan keluarga salah satu faktor utama adalah tingkat pendidikan dan keterampilan petani yang terbatas.

Manajemen keuangan lainnya yang tergolong rendah yaitu manajemen biaya pendidikan anak (biaya pendidikan tambahan/keterampilan) (60 $\%)$.Relatif rendahnya persentase manajemen keluarga terhadap biaya pendidikan anak (biaya pendidikan tambahan/keterampilan) disamping faktor kemauan dan kemampuan orang tua dan anak yang terbatas, fasilitas atau sarana pendidikan keterampilan terbatas atau sulit dijangkau, dan faktor pendapatan keluarga responden yang terbatas untuk keperluan tersebut.

Apabila dirinci berdasarkan persentase dan jenis sumberdaya maka dari ketiga sumberdaya yang dimiliki keluarga contoh, manajemen sumberdaya waktu yang baik tertinggi sebesar 58,4 persen. Artinya, terdapat 58 persen lebih keluarga responden di daerah penelitian menyatakan bahwa mereka merasa cukup baik dalam memanfaat waktu.Persentase keluarga contoh dengan manajemen yang baik lebih banyak pada manajemen sumberdaya anggota keluarga dibandingkan dengan manajemen sumberdaya waktu dan keuangan.

\section{Kesejahteraan Ekonomi Keluarga}

Menurut Lokshin dan Ravallion (Strauss, 2004:63), pengertian kesejahteraan dilihat dari dua pendekatan, yakni: kesejahteraan objektif dan kesejahteraan subjektif. Noll (Milligan et al., 2006:22), melihat bahwa kesejahteraan objektif adalah tingkat kesejahteraan individu atau kelompok masyarakat yang diukur secara rata-rata dengan patokan tertentu baik ukuran ekonomi, sosial maupun ukuran lainnya. Dengan kata lain, tingkat kesejahteraan masyarakat diukur dengan pendekatan yang baku (tingkat kesejahteraan masyarakat semuanya dianggap sama), sedangkan kesejahteraan subjektif adalah tingkat kesejahteraan seorang individu yang dilihat secara personal yang diukur dalam bentuk kepuasan dan kebahagiaan.

\section{Kesejahteraan ekonomi objektif}

Kesejahteraan ekonomi objektif keluarga di wilayah penelitian diukur dengan proxy besarnya pengeluaran keluarga.Hasil pengamatan lapangan, terdapat perbedaan yang cukup mencolok antara pengeluaran kecil (miskin) 
dengan pengeluaran relatif besar (keluarga berkecukupan). Distribusi pengeluaran pada kelompok hampir berkecukupan keatas mencapai 79,4 persen atau hampir mendekati 80 persen. Rata-rata pengeluaran keluarga per tahun di wilayah penelitian adalah sebesar Rp.10.541.000, dan jumlah pengeluaran ini diatas rata-rata tolok ukur kesejahteraan dengan pendekatan Badan Pusat Statistik. Dari jumlah pengeluaran tersebut persentase terbesar dialokasikan untuk pangan $(48,6 \%)$, kemudian diikuti pengeluaran non-pangan (sandang, energi, komunikasi, sosial dan lainnya) sebesar 34 persen, dan terkecil adalah pengeluaran untuk investasi (pendidikan dan kesehatan) hanya sebesar 17,4 persen. Hal ini mengindikasikan bahwa pola konsumsi keluarga terhadap konsumsi pangan masih tergolong besar namun jauh lebih rendah bila dibandingkan dengan hasil penelitian Suhardjo, dan Hardinsyah (1988), Retnaningsih (1995), dan Mangkuprawira (2002) yaitu berkisar antara 60-70 persen.

\section{Kesejahteraan Ekonomi Subjektif}

Berdasarkan hasil wawancara dengan keluarga contoh diperoleh informasi bahwa distribusi tingkat kesejahteraan ekonomi subjektif (subjective economic well-being) di daerah penelitian relatif cukup baik. Hal ini ditandai dengan persentase keluarga di wilayah penelitian yang merasa puas dalam pemenuhan keperluan mereka sehari-hari, baik kebutuhan pangan, non pangan maupun pemenuhan kebutuhan investasi relatif memuaskan yaitu mencapai 68,4 persen. Relatif tingginya persentase masyarakat di wilayah pegunungan yang merasa puas dengan tingkat kesejahteraan yang dimiliki dipengaruhi oleh beberapa faktor pendukung, antara lain: kondisi alam, lapangan kerja, aksesibilitas wilayah dan potensi sumberdaya manusia. Kondisi alam misalnya, oleh karena daerah penelitian berada di daerah pegunungan sehingga kesuburan tanah relatif baik (jenis tanah latosol) dan cukup menguntungkan untuk usaha tanaman pangan, hortikultura maupun perkebunan (Balitbangda Provinsi Jambi, 2006). Seperti diketahui, usaha utama di daerah penelitian adalah usahatani padi sawah, dan perkebunan kulit manis dan kopi disamping itu juga ada usaha tanaman pangan seperti usahatani kentang, cabe, dan pangan lainnya. 


\section{Keterkaitan Kondisi Sosio-mdemografi, dan manajemensumberdaya dengan Kesejahteraan Ekonomi Keluarga}

Keterkaitan kondisi sosio-demografi dan manajemen sumberdaya terhadap kesejahteraan ekonomi keluarga (economic well-being) dianalisis dengan menggunakan model SEM. Melalui model ini dapat diketahui pengaruh atau hubungan antar konstrak secara kausalitas. Sesuai dengan hipotesis, sehingga variabel konstrak terdiri dari empat bagian variabel laten, yakni: (1) Sosiodemografi (Sodem) dengan loading variabel: (X1)(tingkat pendidikan, (X2) keterampilan kepala keluarga, dan (X3) tingkat beban ketergantungan, (2) Manajemen Sumberdaya Keluarga (MSDK) dengan loading variabel: (X1) manajemen waktu, (X2) manajemen jumlah anggota keluarga, dan (X3) manajemen keuangan, (3) Kesejahteraan Ekonomi Objektif (KEO) dengan loading variabel: (Y1) kebutuhan pangan, (Y2) non-pangan, dan (Y3) kebutuhan investasi sumberdaya manusia, (4) Kesejahteraan Ekonomi Subjektif (KES) dengan loading variabel: (Y4) pemenuhan kebutuhan pangan, (Y5) non-pangan, dan (Y6) pemenuhan kebutuhan investasi sumberdaya manusia.

Berdasarkan analisis melalui model SEM dengan program LISREL diperoleh hasil bahwa tingkat validitas konstrak penelitian pengaruh kondisi sosio-demografi dan manajemen sumberdaya keluarga dengan tingkat kesejahteraan ekonomi keluarga di wilayah penelitian cukup valid. Artinya, model-model yang disusun dalam rancangan penelitian cocok atau fit dengan data yang dikumpulkan. Kecocokan atau kehandalan rancangan penelitian dan data yang dijaring ditandai oleh nilai-nilai alat uji yang digunakan. Nilai hasil pengujian model mendekati dan melebihi dari cut-off value yang dikehendaki pada masing-masing alat uji (Tabel 1).

Tabel 1 Goodness of Fit Index Pengaruh Kondisi Sosio-demografi dan Manajemen Sumberdaya terhadap Kesejahteraan Ekonomi Keluarga, 2009

\begin{tabular}{cccc}
\hline No & Goodness of Fit Index & $\begin{array}{c}\text { Cut-off } \\
\text { Value }\end{array}$ & $\begin{array}{c}\text { Wilayah } \\
\text { pegunungan }\end{array}$ \\
\hline 1 & $\mathrm{X}^{2}$ (Chi - Square) = no sign atau lebih kecil & 0,00 & 0,000 \\
2 & RMSEA (Root Mean Square Error of & $\leq 0,08$ & 0,072 \\
& $\quad$ Approximation) & & \\
3 & GFI (Goodness of Fit Index) & $\geq 0,90$ & 0,940 \\
4 & CFI (Comparative Fit Index) & $\geq 0,94$ & 0,972 \\
\hline
\end{tabular}

Sumber: Joreskog \& Sorbom (Freund, dan Carneli, 2004:104) 
Menurut Joreskog dan Sorbom (Freund, dan Carneli, 2004:104) bahwa ada 31 alat uji yang digunakan dalam menguji model. Namun, uji yang sering digunakan dan relevan untuk menguji pengaruh kausalitas antar variabel yaitu mengukur nilai Chi-Square $\left(\mathrm{X}^{2}\right)$, Root Mean Square Error of Approximation (RMSEA), Goodness of Fit Index (GFI) dan nilai Comparative Fit Index (CFI) (Baker, et al., 2005;9). Melalui hasil pengujian model ternyata item loadings untuk variabel-variabel laten dalam model menunjukkan konsistensi internal (reliabilitas) cukup signifikan.

Seperti terlihat pada Gambar 1, variabel latenSosio-demografi (Sodem) misalnya yang terdiri dari tiga dimensi, yakni: tingkat pendidikan, tingkat keterampilan kepala keluarga, dan tingkat beban ketergantungan memiliki nilai loading yang cukup signifikan. Melalui model diketahui bahwa item loadings (X1) tingkat pendidikan kepala keluarga $(\lambda=0,65)$, (X2) keterampilan kepala keluarga $(\lambda=0,50)$, dan $(X 3)$ tingkat beban ketergantungan $(\lambda=0,30)$. Hal yang sama juga ditunjukkan oleh laten Manajemen Sumberdaya Keluarga (MSDK) dengan item loadings (X1) manajemen waktu keluarga $(\lambda=0,41)$, (X2) jumlah anggota keluarga $(\lambda=0,64)$, dan $(X 3)$ manajemen keuangan keluarga $(\lambda=0,68)$.

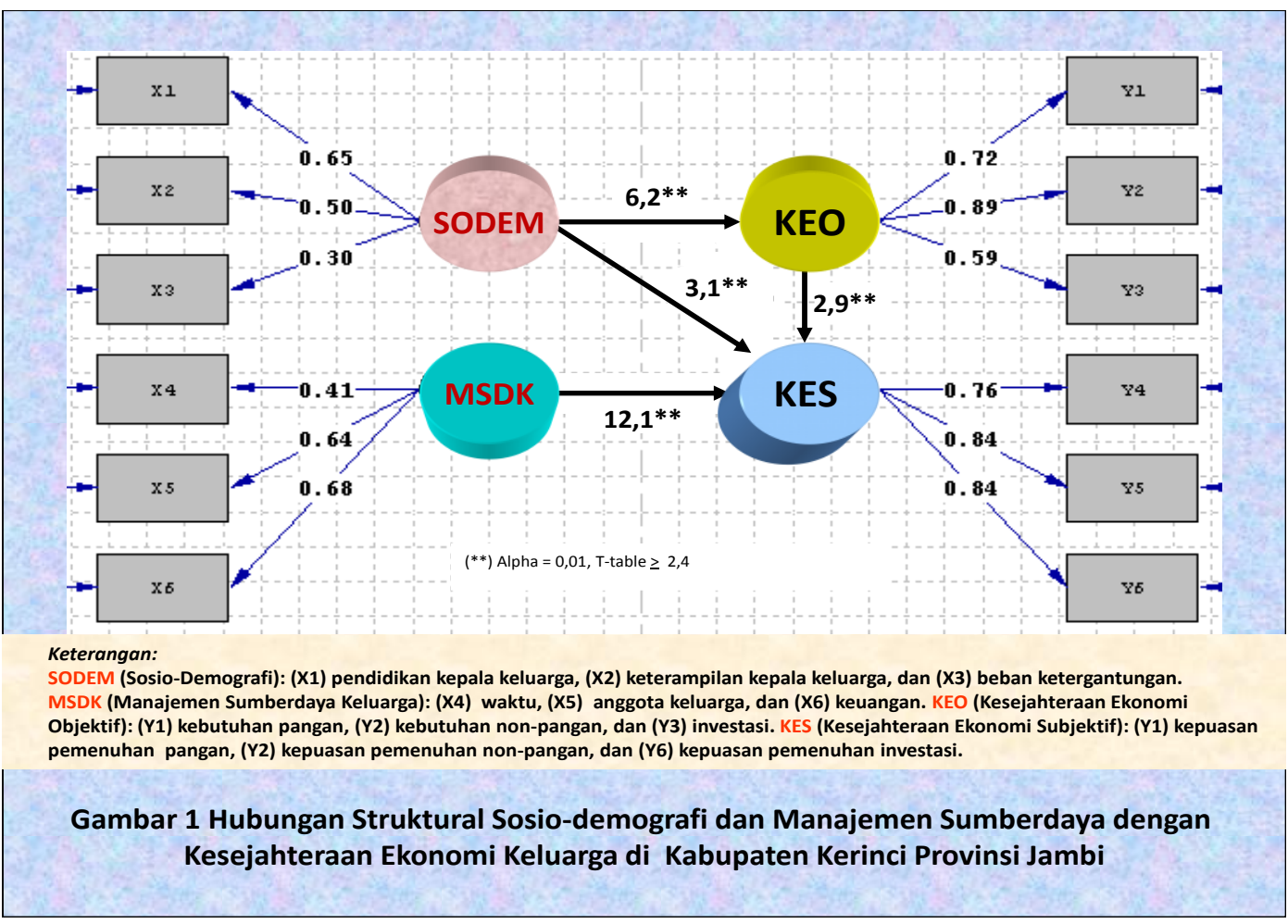

148 | Suandi. Kajian Sosio Demografi dan Manajemen Sumberdaya 
Hasil analisis menunjukkan bahwa variabel sosio-demografi dan manajemen sumberdaya keluarga baik secara langsung maupun tidak langsung berpengaruh positif sangat nyata dan signifikan terhadap tingkat kesejahteraan ekonomi objektif dan kesejahteraan ekonomi subjektif keluarga (subjective economic well-being) dengan nilai betha ( $\beta$ ) masing-masing adalah 6,2 dan 3,1. Hal ini membuktikan hipotesis yang dibangun sebelumnya bahwa varibel sosiodemografi dan variabel manajemen sumberdaya keluarga secara kausalitas dapat mempengaruhi tingkat kesejahteraan ekonomi keluarga. Artinya, semakin baik kondisi sosio-demografi dan manajemen sumberdaya keluarga maka semakin baik pula tingkat kesejahteraan keluarga baik kesejahteraan objektif maupun tingkat kesejahteraan subjektif.

Keterkaitan kondisi sosio-demografi dan manajemen sumberdaya terhadap kesejahteraan ekonomi keluarga sangat erat sekali terutama dalam pemenuhan kebutuhan keluarga. Tinggi rendahnya tingkat pemenuhan kebutuhan keluarga tercermin dari jenis usaha yang ditekuni oleh kepala keluarga. Menurut Suandi (2009), jenis usaha yang tergolong pada kelompok usaha formal (white collard) dengan jam kerja dan tingkat upah yang diperoleh seorang individu lebih terjamin dan tercukupi kebutuhan dasar keluarga, namun pada kelompok usaha yang tergolong pada kelompok blue collard memiliki nilai yang berbeda. Hal ini, semuanya dilatarbelakangi oleh potensi sumberdaya manusia yakni tingkat pendidikan, dan keterampilan kepala keluarga.

\section{SIMPULAN DAN SARAN}

\section{Simpulan}

1) Tingkat kesejahteraan ekonomi objektif proxy pengeluaran keluarga per tahun sebesar Rp.10.541.000, dan jumlah pengeluaran ini diatas rata-rata tolok ukur kesejahteraan dengan pendekatan Badan Pusat Statistik. Persentase terbesar dialokasikan untuk pangan kebutuhan pangan $(48,6 \%)$, non-pangan (sandang, energi, komunikasi, sosial dan lainnya) sebesar 34 persen, dan terkecil adalah pengeluaran untuk investasi (pendidikan dan kesehatan) hanya sebesar 17,4 persen. Dengan kondisi tingkat kesehteraan objektif yang demikian maka kesejahteraan ekonomi subjektif keluarga (subjective economic well-being) di daerah penelitian secara parallel tergolong relatif baik. Hal ini ditandai dengan tingginya persentase $(68,4 \%)$ keluarga yang merasa puas dalam pemenuhan keperluan 
mereka sehari-hari, baik kebutuhan pangan, non pangan maupun pemenuhan kebutuhan investasi sumberdaya manusia.

2) Kondisi sosio-demografi responden di daerah penelitian tergolong rendah. Hal ini tercermin dari rendah persentase responden dalam mengenyam pendidikan formal, dan tingkat keterampilan yang dimiliki. Sebagai contoh, hampir separo dari responden memiliki tinkat pendidikan Sekolah Dasar kebawah. Hal yang sama juga ditunjukkan oleh tingkat keterampilan yang dimiliki, tampaknya tidak jauh berbeda dengan distribusi responden berdasarkan tingkat pendidikan yaitu lebih dari 48 persen responden tergolong pada kelompok yang terbatas mengikuti pendidikan non formal. Dengan arti kata, responden di daerah penelitian mayoritas tidak/belum pernah menerima pendidikan ataupun pelatihan dari istansi pemerintah/swasta baik pada bidang yang ditekuni maupun profesi lainnya.Namun, kondisi tingkat ketergantungan keluarga di daerah penelitian tergolong rendah bahkan lebih rendah dari tingkat ketergantungan pada tingkat Provinsi bahkan Nasional.

3) Faktor manajemen sumberdaya keluarga di daerah penelitian tergolong baik. Dari tiga dimensi yang diukur, semua variabel tersebut menunjukkan persentase yang tinggi. Persentase manajemen waktu keluarga misalnya mencapai 65 persen, persentase manajemen anggota keluarga juga menunjukkan persentase yang relative tinggi bahkan lebih tinggi dari persentase manajemen waktu yaitu mencapai 71 persen, dan persentase manajemen keuangan juga cukup tinggi walaupun tidak sebaik pada pengelolaan sumberdaya waktu dan anggota keluarga yaitu sebesar 60 persen. Artinya, masing-masing dimensi pada variabel manajemen sumberdaya keluarga memiliki pengelolaan yang cukup baik.

4) Hasil analisis menunjukkan bahwa variabel sosio-demografi dan manajemen sumberdaya keluarga baik secara langsung maupun tidak langsung berpengaruh positif sangat nyata dan signifikan terhadap tingkat kesejahteraan ekonomi objektif dan kesejahteraan ekonomi subjektif keluarga (subjective economic well-being) dengan nilai betha $(\beta)$ masingmasing adalah 6,2 dan 3,1.

\section{Saran}

1) Tingkat kesejahteraan individu tidak sama dan tidak dapat disamakan antar manusia maka ke depan, kebijakan pemerintah menetapkan tolok ukur kesejahteraan ekonomi keluarga tidak terbatas pada tolok ukur 
kesejahteraan objektif yang mengukur kesejahteraan dari nilai pendekatan baku. Tetapi sudah melihat kepada kecukupan masyarakat dengan pendekatan kepuasan (subjective economic well-being).

2) Pemberdayaan kepada masyarakat luas dan petani tidak hanya terbatas kepada pemberdayaan terhadap pengembangan usaha, namun perlu juga mempertimbangkan potensi sumberdaya manusia dan pengelolaan sumberdaya.

\section{DAFTAR PUSTAKA}

Anonim, 2003.Millenium Development Goals (MDGs):In Asia and the Facific. Meeting the Chalenger of Poverty Reduction. New York: United Nations.

Baker Kristine R, Ofstedal Mary Beth, Zimmer Zachary, Tang Zhe, dan Chuang Yi-Li. 2005.Reciprocal Effects of Health and Economic well-being among Older Adults in Taiwan and Beijing.Working Paper No. 197. New York: Policy Research Division. Population Council. Inc. ISSN: 1554-8538.

[Balitbangda Provinsi Jambi] Badan Penelitian dan Pengembangan Daerah Provinsi Jambi. 2003. “Evaluasi Kebutuhan Penempatan Transmigrasi di Provinsi Jambi." Jambi: Badan Penelitian dan Pengembangan Daerah (Balitbangda) Provinsi Jambi.

Bollen, K.A. 1989. Stuctural Equation with Latent Variable. New York: John Wiley \& Sons, Inc.

Freund, Anat, dan Abraham, Carneli. 2004. "The Relationship between Work Commitment and Organizational Citizenship Behavior among Lawyers in The Private Sector." The Journal of Behavioral and Applied Management. Vol. 5, No.2, p:93-113, winter 2004.

Guhardja, Suprihatin, Hidayat Syarief, Hartoyo, dan Herien Puspitawati. 2002. Pengembangan Sumberdaya Keluarga. Jakarta: BPK Gunung Mulia.

Milligan Sue, Fabian Angela, Coope Pat, dan Errington Chris. 2006. Family Wellbeing Indicators from the 1981-2001 New Zealand Cencuses. New Zealand: Published in June 2006 by Statistics New Zealand in Conjunction with The University of Auckland and University of Otago. 2006, ISBN 0-478-26982-X.

Mangkuprawira, Syafri. 2002. "Analisis Pendapatan dan Pengeluaran Keluarga di Daerah Industri Tenun Pedesaan." Media Gizi \& Keluarga. Bogor: Jurusan Gizi Masyarakat \& Sumberdaya Keluarga Fakultas PertanianInstitut Pertanian Bogor. Vol 25/2-2002.ISSN 0216-9363.

Mantra, Ida Bagus. 2000. Dasar-dasar Demografi. Yogyakarta: Pusat Penelitian Kependudukan Universitas Gadjah Mada Yogyakarta.

Mubyarto. 1992. Menanggulangi Kemiskinan. Yogyakarta: Aditya Media. 
Myers, RH. 1990. Classical and Modern Regression with Applications. Boston: Second Edition. PWS-KENT Publishing Company.

Strauss, John, Kathleen Beegle, Agus Dwiyanto, Yulia Herawati, Daan Pattinasarany, Elan Satriawan, Bondan Sikoki, Sukamdi, dan Firman Witoelar, 2004. Indonesian Living Standards: Before and After the Financial Crisis. RAND Corporation, Santa Monica, USA, and Institute of Southeast-Asian Studies, Singapure.

Suandi, dan Bambang. 2003. Profil Statistik dan Indikator Gender di Propinsi Jambi. Jakarta: Kerjasama Kantor Badan Pusat Statistik (BPS) Jakarta, Kantor Menteri Negara Pemberdayaan Perempuan, dan Japan International Cooperation Agency (JICA).

Suandi, 2009.“Kajian Modal Sosial dan Kesejahteraan Ekonomi Keluarga Petani di Daerah Perdesaan Provinsi Jambi". Laporan Penelitian. Dibiayai oleh DP2M Dikti Tahun 2009, Tahun Anggaran 2009 sesuai dengan Surat Perjanjian Pelaksanaan Hibah Kompetitif Penelitian Sesuai Prioritas Nasional Nomor Kontrak: 526/SP2H/PP/ DP2M/VII/2009, Tanggal 21 Juli 2009. Jambi: Lembaga Penelitian Universitas Jambi. 